\title{
Evaluation of the productivity of spring grain crops with two-axis use in the Krasnoyarsk forest-steppe
}

\author{
Larisa Baykalova $^{1, *}$, Alexander Karvel $^{1}$, and Vladimir Novokhatin ${ }^{2}$ \\ ${ }^{1}$ Krasnoyarsk State Agrarian University, 660049, Krasnoyarsk, Russia \\ ${ }^{2}$ Research Institute of Agriculture of the Northern Trans-Urals - branch of the TSM NC SB RAS, \\ 625501, Tyumen Region, Russia
}

\begin{abstract}
The application of two-axis use on varieties of spring barley, wheat and triticale is considered. In the conditions of the forest-steppe of the Krasnoyarsk Territory, it is possible to obtain a second harvest in the form of grain with the repeated use of crops. The best varieties of grain crops for two-axis use were identified: barley - Zhikhar and Emelya, wheat - Rix, Triticale - Erythrospermum d. 94/11-19. With two cuts (grain + green mass), the energy productivity of the Zhikhar variety was 32,2 $\mathrm{GJ} / \mathrm{ha}$, the Emelya variety-33.7 GJ/ha, the Riks variety-63.4 GJ/ha, the Erythrospermum d variety. 94/11-19 - 60,3 GJ/ha. By the control of one mowing, the energy productivity of the Zhikhar and Emelya varieties was $122,9 \%$ and $97,1 \%$, the energy productivity of the Riks and Erythrospermum varieties 94/11-19-197,5\% and 182,2 \%. An increase in the protein content in the grain of barley, wheat and triticale with twomowing use by $0.2-3.9 \%$ was noted.here
\end{abstract}

\section{Introduction}

In the Krasnoyarsk Territory, characterized by extreme climatic conditions, the issue of realizing the adaptive potential of grain crops is particularly relevant. Grain crops in this region are widely used for fodder purposes. In addition to grain, green mass is used for animal feed, for the production of hay and haylage. More than a million tons of harvested feed in the region is accounted for by haylage, of which $80 \%$ is for grain production, which is based on grain feed crops $[1,2]$. An important role in realizing the adaptive potential of grain crops is the optimization of cultivation technology [3, 4]. An increase in the share of climate in the variability of grain crop productivity and the scope of yield variation was noted by A. A. Zhuchenko [5].

In his opinion, an increase in the share of grain crops in areas extreme in soil-climatic and weather conditions from $40 \%$ to $60 \%$ will increase their resistance to abiotic and biotic stresses. In the Krasnoyarsk Territory, grain crops occupy about $63 \%$ of the total cultivated area.

\footnotetext{
* Corresponding author: kos.69@mail.ru
} 
So, in 2020, the total sown area was 1,476 thousand hectares, of which cereals and legumes - 933,7 thousand hectares, in addition, 228,5 thousand hectares are sown with annual cereals and legumes mixtures, which include spring cereals. The existing structure of sown areas provides for an increase in the share of gray bread, since this is not enough to satisfy primarily the needs of livestock, as well as food needs [6].

The two-axis use of spring grain crops is part of the creation of organic farming in Russia, as it allows you to get more environmentally friendly products per unit area without the use of chemicals. The issues of assessing the productivity of modern varieties of barley, wheat and triticale remain important and have not been studied. Taking into account the importance of gray bread in the issue of ensuring food security of the Krasnoyarsk Territory and Russia as a whole, we note the high relevance of the topic chosen for the study.

The aim of the work is to analyze the productivity of barley, wheat and triticale varieties under two-axis use in the conditions of the Krasnoyarsk forest-steppe. In this regard, the following tasks were set:

1. to evaluate the varieties of gray bread by the yield of green mass and grain;

2. to establish the productivity of barley, feed wheat and triticale varieties with two-axis use;

\section{Research methods}

The studies were carried out in 2018-2020. at the experimental field of the Department of Plant Growing, Breeding and Seed Growing at the Borsky Scientific and Production Center of the Sukhobuzimsky District of the Krasnoyarsk Territory. The soil of the experimental site is represented by leached black soil. Tillage was carried out in accordance with the requirements of zonal farming systems and generally accepted recommendations for the zone. The area of each variant of the experiment is $56-112 \mathrm{~m} 2$, the method of sowing is ordinary, with a SSNP-1.6 seeder.

The cultivation technology in the experiment is generally accepted, zonal for gray loaves. The predecessor was a busy steam. The seeding coefficient of barley is 5.0 million wx. grains/ha, wheat and triticale -5.5 million hss. grains/ha. The grain harvest was recorded by direct combining on an area of $10 \mathrm{~m} 2$. The repetition is fourfold. Mowing on the green mass was carried out in the phase of entering the tube, on the grain - in the phase of waxy - full ripeness. Records, observations, and productivity calculations were carried out according to the methodology of the V. R. Williams Institute of Feed Research [7]. Statistical processing of the results was carried out according to the methods of B. A. Dospekhov [8, 9] and Snedekor D. U. [10].

The content of feed units and the energy content of the green mass were taken from reference data $[11,12]$ and qualitative analysis data. The qualitative analysis of grain was carried out in the research and testing center for quality control of agricultural raw materials of the Krasnoyarsk State Agrarian University according to the generally accepted methods of zootechnical analysis of feed [13, 14].

In 2018, 2019, the varieties included in the list of breeding achievements approved for use in the Krasnoyarsk Territory were studied. Barley: Biom, Uvatsky, Zhikhar, Emelya, Krasnoyarsk 91, Acha, Takmak and Olenek. In 2020, the collection was replenished with promising Russian and foreign varieties of grain crops of the feed direction. Barley varieties were included: Sobolek (Krasnoyarsk Research Institute of Agriculture), Simbat and Zhan (Kazakh Research Institute of Agriculture and Crop Production), NIIS-1 or Slavny (Research Institute of Agriculture of the Northern Trans-Urals); wheat: Tyumen 29 and Riks; spring triticale: Erythrospermum 56 /314, Erythrospermum 57 / 405; Erythrospermum $94 / 1119$, Erythrospermum $112 / 1020$ (Research Institute of Agriculture of the Northern Trans-Urals); 
Single-bite use was taken as a control in assessing productivity, barley of Biom variety was taken in assessing yield, and Ricks wheat variety was taken in assessing wheat yield and triticale.

Weather conditions during the years of the experiments were contrasting, both in terms of the distribution of temperatures and precipitation in individual months, and in general for the growing periods. In 2018, precipitation fell significantly below normal in May, June, July, and August - from 11 to $33 \mathrm{~mm}$. In 2019, May and July were dry, August and September were close to the average long-term value in terms of precipitation, and June was significantly higher than the norm. In June 2019, $106 \mathrm{~mm}$ of precipitation fell at a norm of $46.8 \mathrm{~mm}$. In 2020, the amount of precipitation exceeded the norm in all months of the growing season, especially significantly in June and July. In June 2020, precipitation fell by $47.4 \mathrm{~mm}$, in July - by $64 \mathrm{~mm}$ above normal. According to the indicator of the hydrothermal coefficient, 2020 was overwetted, 2019 was not sufficiently moist, and 2018 was dry.

The vegetation periods of the research years were warmer in comparison with the average long-term value. The average air temperature ranged from $150 \mathrm{C}$ in 2020 to 16.5 0C in 2018, with a norm of 13.1 0C. In general, the years of research were contrasting in terms of heat and moisture availability, which made it possible to make a comprehensive assessment of the experimental material.

\section{Research results}

Most of the studied barley varieties for the period 2018-2020 had a higher grain yield with single-grain use. Only the Zhikhar and Emelya varieties showed a higher grain yield with two-mowing (Fig. 1). The increase in yield to one mowing of the Zhikhar variety was 0.89 $\mathrm{t} / \mathrm{ha}$ or $38 \%$, the Emelya variety was $0,47 \mathrm{t} / \mathrm{ha}$ or $16,7 \%$.

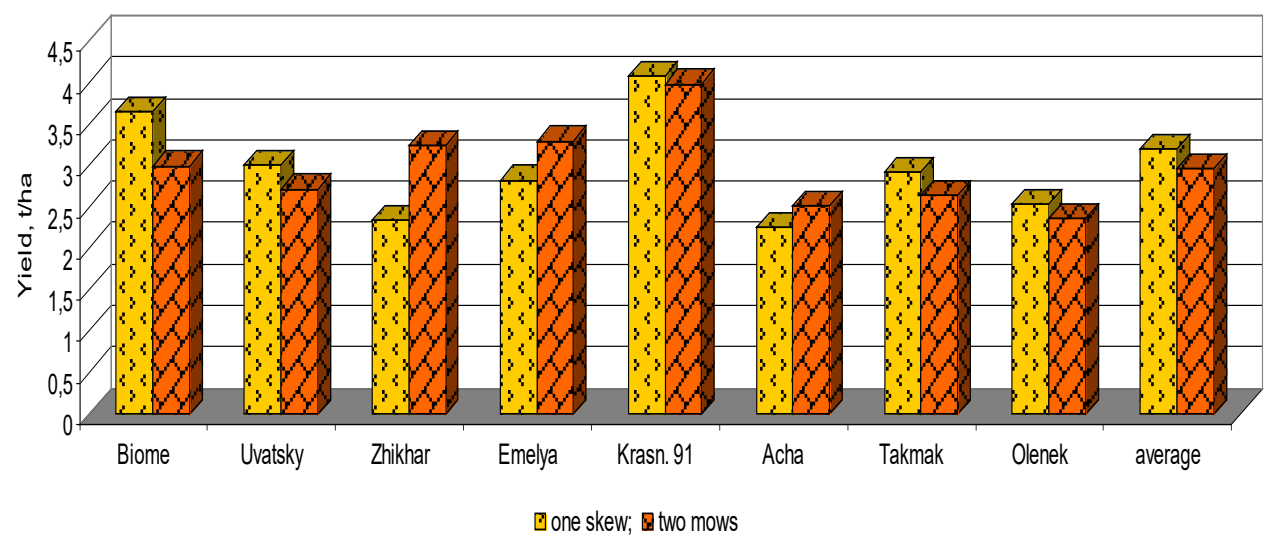

Fig. 1. Grain yield of barley varieties with single-axis and double-axis use, $\mathrm{t} / \mathrm{ha}, 2018-2020$. Note: one mowing of NSR05 0,10 t/ ha, two mowing of NSR05 0,08 t/ha

The yield of the green mass of barley varieties depended on the weather conditions of the years of research and the variety. In 2018, there were no significant differences in barley varieties in comparison with the Biome control, the yield of green mass was from $3.26 \mathrm{t} / \mathrm{ha}$ for the Emelya variety to $3.62 \mathrm{t} / \mathrm{ha}$ for the Takmak variety. In 2019, the Zhikhar varieties exceeded the control in terms of green mass yield by $4.97 \mathrm{t} / \mathrm{ha}$, Emelya - by 1.35 $\mathrm{t} / \mathrm{ha}$ and Krasnoyarsk 91 - by $1.12 \mathrm{t} / \mathrm{ha}$, the other varieties were inferior to the Biome in terms of the named indicator. In 2020, the studied barley varieties were less productive in 
terms of green mass than the Biome control. On average, during the research period, the maximum yield of green mass was obtained by Zhikhar and Emelya varieties, which exceeded the Biome control by $1.30 \mathrm{t} /$ ha and $0.34 \mathrm{t} / \mathrm{ha}$. The yield of the green mass of the Krasnoyarsk 91 variety was at the control level, the other varieties were inferior to the control (Fig. 2).

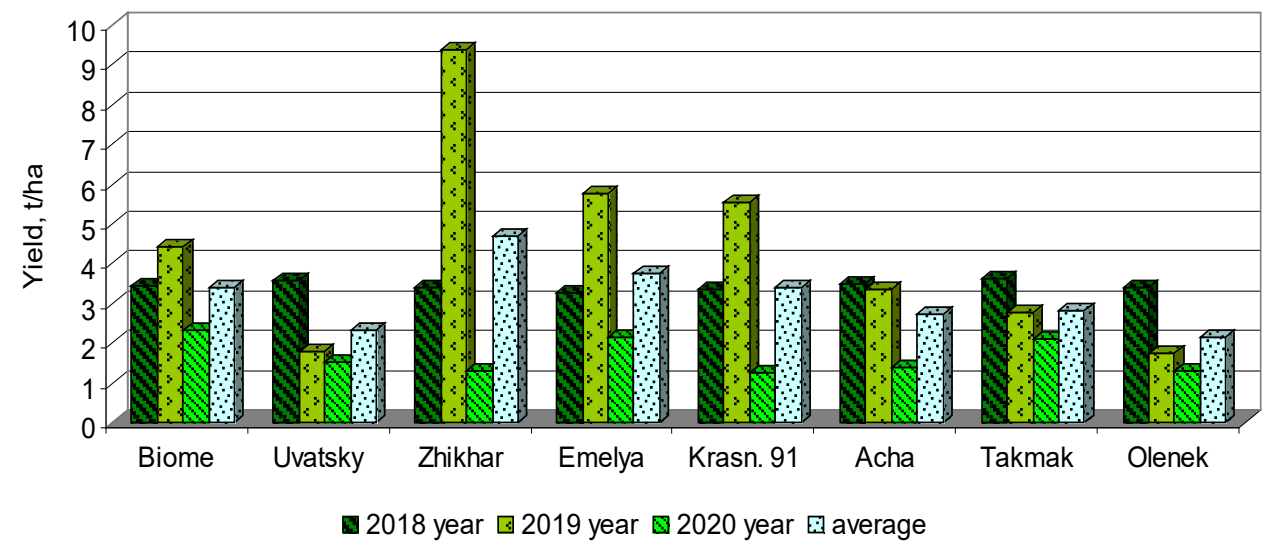

Fig. 2. Yield of green mass of barley varieties with two-axis use, $t /$ ha, 2018-2020.

Note: NSR05 20180.36 t / ha, NSR05 20190.53 t/ha, NSR05 20200.11 t/ha, NSR05 average 0.07 t/ha.

The data presented in Table 1 indicate that the Zhikhar and Emelya varieties have a pronounced remontance and are capable to provide two crops per year, the energy productivity of which exceeds the energy productivity of one cut or is close to it.

Table 1. Influence of the method of use on the energy productivity of barley varieties, GJ/ha, 2018-2020 years.

\begin{tabular}{|l|c|c|c|}
\hline \multirow{2}{*}{ Variety } & \multicolumn{2}{|c|}{ Using } & $\begin{array}{c}\% \\
\text { to control }\end{array}$ \\
\cline { 2 - 3 } & $\begin{array}{c}\text { single -grain } \\
\text { (grain) }\end{array}$ & $\begin{array}{c}\text { two -axis (grain }+ \\
\text { green mass) }\end{array}$ & 80,3 \\
\hline 1. Biome & 42,1 & 33,8 & 81,0 \\
\hline 2. Uvatsky & 36,3 & 29,4 & 122,9 \\
\hline 3. Zhikhar & 26,2 & 32,2 & 97,1 \\
\hline 4. Emelya & 34,7 & 33,7 & 65,4 \\
\hline 5. Krasnoyarsk 91 & 48,0 & 31,4 & 41,8 \\
\hline 6. Acha & 53,3 & 22,3 & 77,6 \\
\hline 7. Takmak & 34,0 & 26,4 & 70,4 \\
\hline 8. Olenek & 27,7 & 19,5 & 75,7 \\
\hline average & 37,8 & 28,6 & \\
\hline $\begin{array}{l}\text { The smallest significant } \\
\text { difference 05 A variety }\end{array}$ & 2,6 & 0,7 & \\
\hline $\begin{array}{l}\text { The smallest significant } \\
\text { difference 05 A year }\end{array}$ & 1,6 & 0,4 & \\
\hline $\begin{array}{l}\text { The smallest significant } \\
\text { difference 05A×5 }\end{array}$ & 4,4 & 1,2 & \\
\hline
\end{tabular}

Evaluation of the use of wheat and triticale in energiaproductions showed the advantage of the two harvests in all studied varieties and samples (tab. 2). Results daukenova use of feed wheat and triticale in 2020 showed that in conditions of excessive moisture, these 
samples has shaped not only the most energiaproductions two cuts from $137,5 \%$ in Eritrospermum $112(10-20)$ to $197,5 \%$ in the variety RIX to control one mowing, but a greater grain yield (table. 2 ).

Table 2. The influence of the method of use on the productivity of wheat and triticale, 2020 year.

\begin{tabular}{|c|c|c|c|c|c|}
\hline \multirow{3}{*}{ Variety, sample } & \multicolumn{3}{|c|}{ Yield, t / ha } & \multicolumn{2}{|c|}{$\begin{array}{l}\text { Energy } \\
\text { productivity, GJ/ha }\end{array}$} \\
\hline & \multirow{2}{*}{$\begin{array}{c}\text { one skew } \\
\text { grain, } \\
\text { control }\end{array}$} & \multicolumn{2}{|c|}{ two mows } & \multirow{2}{*}{$\begin{array}{l}\text { one slope, } \\
\text { control }\end{array}$} & \multirow{2}{*}{$\begin{array}{l}\text { two } \\
\text { mows }\end{array}$} \\
\hline & & grain & $\begin{array}{l}\text { green } \\
\text { mass }\end{array}$ & & \\
\hline 1. Rics, control & 2,27 & 3,31 & 9,49 & 32,1 & 63,4 \\
\hline 2. Tyumen 29 & 1,85 & 1,89 & 8,53 & 27,0 & 42,0 \\
\hline 3. Erythrospermum 56 (314) & 2,68 & 3,54 & 5,11 & 38,0 & 58,7 \\
\hline 4. Erythrospermum 57 (405) & 2,78 & 3,09 & 6,25 & 39,7 & 56,0 \\
\hline 5. Erythrospermum 94 (11-19) & 2,38 & 3,02 & 8,55 & 33,1 & 60,3 \\
\hline 6. Erythrospermum 112(10-20) & 2,00 & 2,27 & 3,35 & 27,7 & 38,1 \\
\hline The smallest significant difference 05 & 0,25 & 0,22 & 0,20 & 3,5 & 3,0 \\
\hline
\end{tabular}

Of particular interest is the increase in the protein content in the grain of cereals with two-axis use. In nine of the twelve barley varieties studied, the protein content in two-axis use was higher than in one-axis use. In the Zhikhar variety, depending on the method of use, the protein content did not change, in the Acha and Sobolek varieties, it was large with single-axis use. The protein content in single-axis use ranged from $10 \%$ in the Krasnoyarsk 91 variety to $14.8 \%$ in the Sobolek variety. With two-axis use, the protein content in the grain ranged from $13.6 \%$ in the Acha variety to $15.1 \%$ in the Emelya variety.

All the studied varieties of wheat and triticale also had a higher protein content in the grain with two-axis use. On average, the content was $2.2 \%$ higher.

In terms of the content of exchange energy and feed units, higher indicators were obtained with single-axis use, both for barley varieties, and for wheat and triticale varieties. Grain of barley varieties with dredged use exceeded the same indicator with double-skewed use in terms of the content of exchange energy by $0.38 \mathrm{MJ} / \mathrm{kg}$, in terms of the content of feed units-by 0.08 feed units $/ \mathrm{kg}$. In wheat and triticale, the content of exchange energy with single-axis use ranged from $13.9 \mathrm{MJ} / \mathrm{kg}$ in the Erythrospermum 94 / 11-19 variety to $14.6 \mathrm{MJ} / \mathrm{kg}$ in the Tyumen 29 variety. With two-axis use, the content of exchange energy in the grain ranged from $13.19 \mathrm{MJ} / \mathrm{kg}$ in the Tyumen 29 variety to $14 \mathrm{MJ} / \mathrm{kg}$ in the Erythrospermum 94 / 11-19 variety. The content of feed units in grain with single-axis use ranged from 1.55 feed units $/ \mathrm{kg}$ for the Erythrospermum $94 / 10-20$ variety to 1.73 feed units $/ \mathrm{kg}$ for the Tyumen 29 variety, with two-axis use - from 1.41 feed units $/ \mathrm{kg}$ for the Tyumen 29 variety to 1.59 feed units/kg for the Erythrospermum 94 variety.

\section{Conclusions}

Thus, in the conditions of the forest-steppe of the Krasnoyarsk Territory, it is possible to obtain a second crop in the form of grain with repeated use of sowing. The Zhikhar 3,23 t/ha and Emelya 3,29 varieties showed a higher grain yield with two-axis use, it exceeded the yield of single-axis use by $0,89 \mathrm{t} / \mathrm{ha}$ and $0,47 \mathrm{t} / \mathrm{ha}$. The same barley varieties showed the highest yield of green mass of 4,69 and 3,73 $\mathrm{t} /$ ha. Feed varieties of wheat and triticale showed a higher grain yield with two-axis use.

The best grain yields in obtaining the second crop in the form of grain were the varieties Riks, Erythrospermum D. 56/314 and Erythrospermum D. 94/11-19. The maximum yield 
of green mass was obtained from Rics wheat 9,49 $\mathrm{t} /$ ha and Erythrospermum wheat $\mathrm{d}$. 94/11-19 8,55 t/ha.

Zhikhar and Emelya provided higher energy productivity with two-mowing use among barley varieties $-122,9 \%$ and $97,1 \%$ to one mowing. The energy productivity of wheat and triticale varieties to control one mowing was from $141,1 \%$ to $197,5 \%$. The best in terms of energy productivity were Rix wheat, which showed 197,5\% and triticale Erythrospermum D. 94/11-19 - 182,2 \% to one mowing.

The grain of barley, wheat and triticale varieties exceeded the protein content in twomowing use of the single-mow, but were inferior to it in terms of the content of metabolic energy and feed units, with the exception of triticale Erythrospermum d. 94 / 11-19, in which a higher content of metabolic energy and feed units was noted in grain when re-using sowing.

\section{References}

1. L.P. Baikalova, J.F. Edilicek, V.A. Kolesnikov, A.I. Mashanov, Vestnik Krasgau 5, 102-108 (2018)

2. L.P. Baikalova, Y.I. Serebrennikov, Vestnik Krasgau, 1, 26-33 (2017)

3. N. Rendov, A. Gladkikh and E. Nekrasova, IOP Publishing. IOP Conf. Series: Earth and Environmental Science, 395 (2019)

4. A. Gladkikh, N. Rendov, E. Nekrasova and S. Mozyleva, The Fifth Technological Order: Prospects for the Development and Modernization of the Russian AgroIndustrial Sector (TFTS 2019), 393 (2019).

5. A.A. Zhuchenko, Resource potential of grain production in Russia (theory and practice), 825 (2004)

6. Office of the Federal state statistics service on Krasnoyarsk territory, Republic of Khakassia and the Republic of Tuva, https://krasstat.gks.ru (2021)

7. Methodological guidelines for conducting field experiments with forage crops, 197 (1987).

8. B.A. Dospekhov, Methodology of field experience, 351 (1985)

9. B.A. Dospekhov, Methodology of field experience. Ed. 6th, reprint. and EXT., 351 (2011)

10. D.W. Snedecor Statistical methods in the application and research in agriculture and biology, 503 (1961)

11. Chemical composition and nutritional value of feed of the Krasnoyarsk territory, 161 (1997)

12. G.A. Romanenko, A.I. Tyutyunnikov, P.L. Goncharov, Forage plants of Russia, 370 (1999)

13. E.A. Petukhov, R.F. Bessarabova, L.D. Aleneva, O.A. Antonova, Zootechnical analysis of forages, 239 (1989)

14. I.M. Skurikhin, V.A. Tutelyan, Manual of methods of analysis of the quality and safety of food products, 342 (1998) 